\title{
A Review of Bio-Processing of Market Crop Waste to Poultry Feed in Uganda
}

\author{
Noah Kisuule ${ }^{1}$, Nicholas Kiggundu ${ }^{1} \&$ Noble Banadda ${ }^{1}$ \\ ${ }^{1}$ Department of Agricultural and Biosystems Engineering, Makerere University, Kampala, Uganda \\ Correspondence: Noah Kisuule, Department of Agricultural and Biosystems Engineering, Makerere University, P. \\ O. Box 7062, Kampala, Uganda. Tel: 256-7-7244-3552. E-mail: kiggundu@caes.mak.ac.ug
}

Received: October 5, 2020

Accepted: November 28, 2020

Online Published: December 1, 2020

doi:10.5539/jsd.v14n1p26

URL: https://doi.org/10.5539/jsd.v14n1p26

\begin{abstract}
This paper reviews the current state of bio-processing of market waste to poultry feed in Uganda. A focus was put on crop wastes since previous studies have indicated that, they contribute the biggest percentage (about 90\%) of the total organic waste generated in markets. These wastes majorly comprise of fruits and vegetables like mangoes, pineapples, jackfruit, watermelon, cabbage among others. They are usually in form of residual stalks, leaves, peels, and damaged/rotten crops. Crop wastes are rich in various bioactive and nutraceutical compounds, like carotenoids, polyphenols and dietary fiber. The wastes are a major worthwhile raw material and present feasible solutions to the problems of poultry feed scarcity and high costs associated with the conventional feed stuffs. This transformation can be achieved by developing appropriate technologies for valorization of wastes by nutrient enrichment. In concern to this, solid state fermentation (SSF) and rearing insects and earthworm using crop wastes are the promising novel technologies. High value added products/feeds can be produced through microbial fermentation of crop wastes. Insect protein can also be produced to replace the expensive silver fish and soybean protein sources. The review indicated that, the technologies have not been fully cherished within the country's poultry feed industry. All the attempts and work done are still under research and pilot scale level. However, the on-going endeavors are continued widely to better conversion technologies in order to produce products that are safe for poultry feeding. Lastly, the limitations and strategies for processing poultry feed from market waste are reviewed.
\end{abstract}

Keywords: bio-processing, poultry feed, solid-state fermentation, insect breeding, market crop waste, nutrient enrichment

\section{Introduction}

Ugandan crops are transported and marketed in raw form, by traders who link farmers to urban consumers. The crops are transported to various consumer markets with large volumes of inedible parts. This practice has been reported by Amoding (2007) as one of the key sources of solid waste in urban areas. It is estimated that over 1,000 tons of solid waste is generated daily in Kampala alone (Abondio et al., 2020). Kinobe et al. (2015) and Komakech et al. (2014) report that, more than $90 \%$ of the total solid waste generated in Kampala is organic in nature. This largely constitutes of crop residues generated within the markets. The wastes are usually in form of residual stalks, leaves, roots, peelings, packaging papers/covers and damaged or rotten crops (Sabiiti, 2011).

Suitable disposal of wastes especially in urban centers has been a persistent problem in Uganda (Mboowa et al., 2017; Miito \& Banadda, 2016). For instance, of the total waste generated in Kampala City, only about $40 \%$ is collected and dumped at Kiteezi land fill site (Komakech et al., 2014). The rest is disposed of irresponsibly or for several reasons left uncollected in markets (Komakech, 2014). It is wholly due to inadequate landfills and the high rates associated in contracting private waste collection companies (Raji and Onu, 2017). Market wastes can cause severe environmental and health problems. These include; odor, harborage for harmful insects and can contribute to greenhouse gas emission during decomposition (Mboowa et al., 2015; Shalini \& Gupta, 2010). Huge amounts of precious raw materials could also be lost if the wastes are not handled well. This can consequently lead to serious ecological damages (Padam et al., 2014; Yabaya \& Ado, 2008). Contrastingly, crop wastes can be vital resources since they are widely available, almost free and renewable (Sabiiti et al., 2004). Therefore, their utilization needs urgent attention as it can minimize environmental pollution and improve the present situation by creating new products. 
There have been numerous attempts at functional utilisation of market crop wastes in Uganda. These include; production of energy for heating purposes and livestock feeds particularly in the poultry industry. Positive findings have been reported by some researchers about the utilization of these abundant and inexpensive wastes as alternative feed ingredient in poultry ration (Leib et al., 2016; Lohri et al., 2017). The studies reveal that; crop wastes have a greater potential to help reduce the over-dependence on conventional feeds. The intention is to reduce the high costs associated with the common conventional feeds and environmental pollution. Additionally, other researchers have compiled nutrient compositions of some selected market wastes and proposed their inclusion in livestock feed (Georganas et al., 2020; Mahgoub et al., 2020; Yitbarek, 2019; Zubairu et al., 2018). Some fruit and vegetable wastes are rich in various bioactive and nutraceutical compounds, like carotenoids, polyphenols, dietary fiber, vitamins, enzymes and oils (Sagar et al., 2018). The regular use of market wastes as feed for poultry birds has a twofold potential: tackle food insecurity and can reduce the problems associated with waste disposal in Uganda and other developing countries (Dou et al., 2017). The process is however possible after appropriate processing using efficient techniques.

Therefore, the objective of this paper was to review current developments in management and utilization of market crop wastes in production of poultry feed using bioprocessing techniques, a case of Uganda. The strategies to enhance the adoption and use of these techniques have also been suggested based on the current limitations for the technology.

\section{Major Markets and Composition of Market Crop Wastes}

\subsection{Major Markets (Food collection centers) in Kampala}

Kampala has more than 56 food markets (Schöbitz et al., 2014). The main ones include; St Balikudembe (Owino), Kalerwe, Nateete, Kasubi, Kiseka, Katwe, Kamwokya, Nakasero, Nakawa, Wandegeya and Kibuye (Kinobe et al., 2015; Schöbitz et al., 2014).

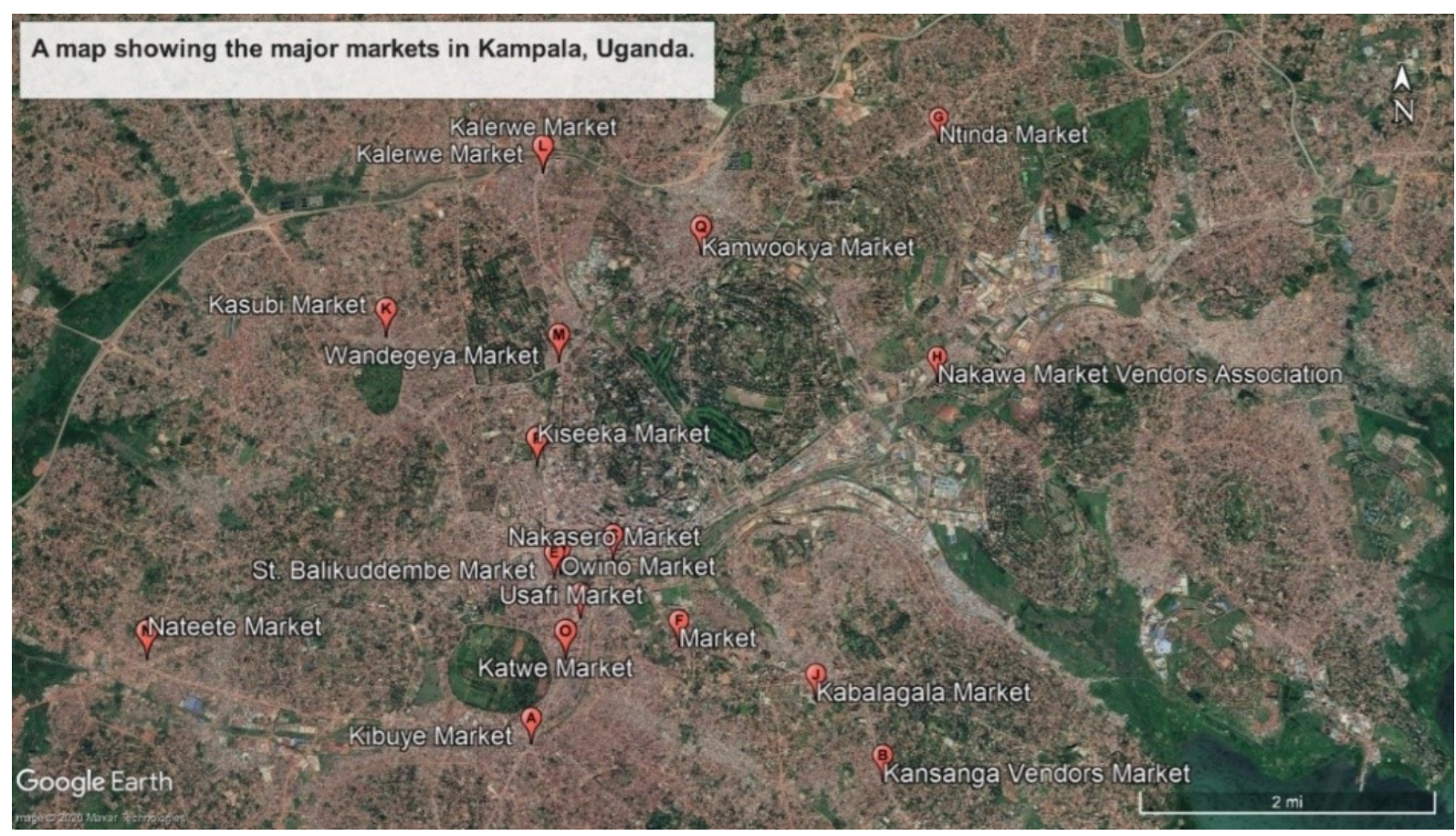

Figure 1. Major food collection markets/centers in Kampala (Captured from Google Earth) 
Table 1. Location Coordinates of main markets in Kampala

\begin{tabular}{llcc}
\hline No. & Market & Eastings (m) & Northings (m) \\
\hline 1 & Kasubi & 36800.07 & 450575.81 \\
2 & Kalerwe & 38747.98 & 452336.02 \\
3 & Wandegeya & 36499.18 & 452336.73 \\
4 & Kamwokya & 37773.78 & 454194.15 \\
5 & Kiseka & 35312.88 & 454194.15 \\
6 & Nateete & 33167.43 & 448070.17 \\
7 & Katwe & 33120.17 & 452710.46 \\
8 & Nakawa & 36449.95 & 456905.34 \\
9 & Nakasero & 34430.08 & 453219.55 \\
10 & St. Balikudembe & 34271.29 & 452631.95 \\
11 & Ntinda & 38680.01 & 457154.53 \\
12 & Kibuye & 32428.18 & 452347.69 \\
\hline
\end{tabular}

Market locations and the GPS coordinates (UTM) of the main markets are presented in Figure 1 and Table 1.

\subsection{Composition of Market Crop Waste}

The biggest percentage of market wastes comes from fruits and vegetables (figure 2) like mangoes, pumpkins, pine apples, jackfruit, water melon, cabbage, greens, among others (Nsubuga et al., 2019; Schöbitz et al., 2014).

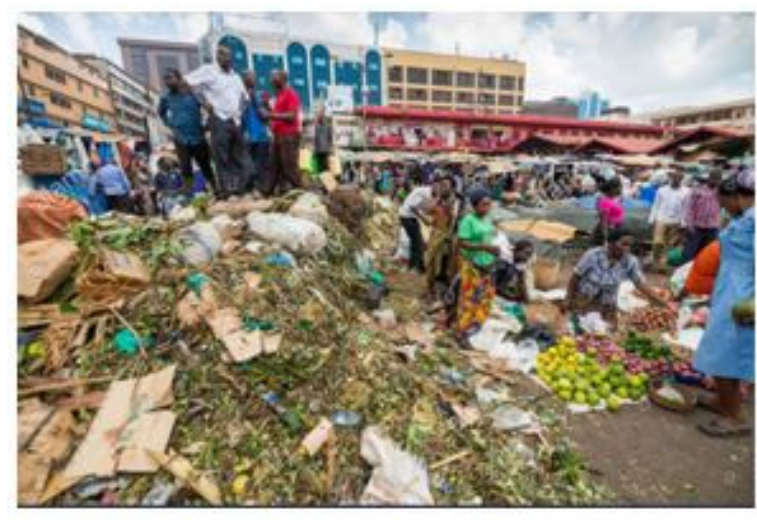

(a)

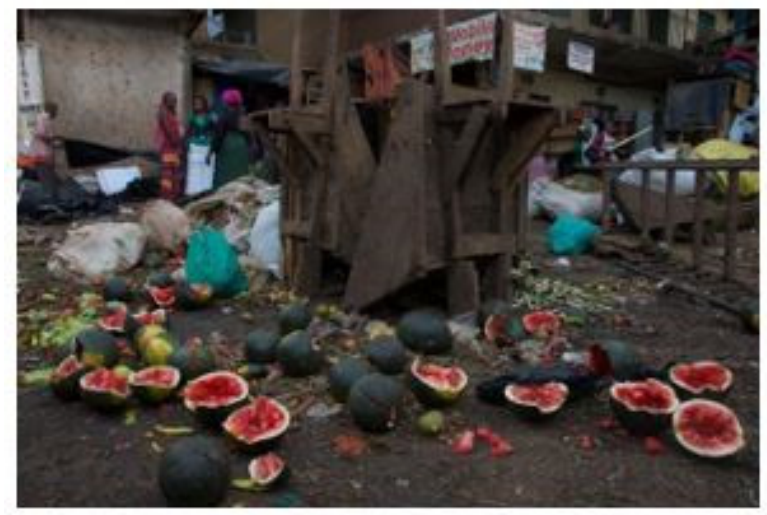

(c)

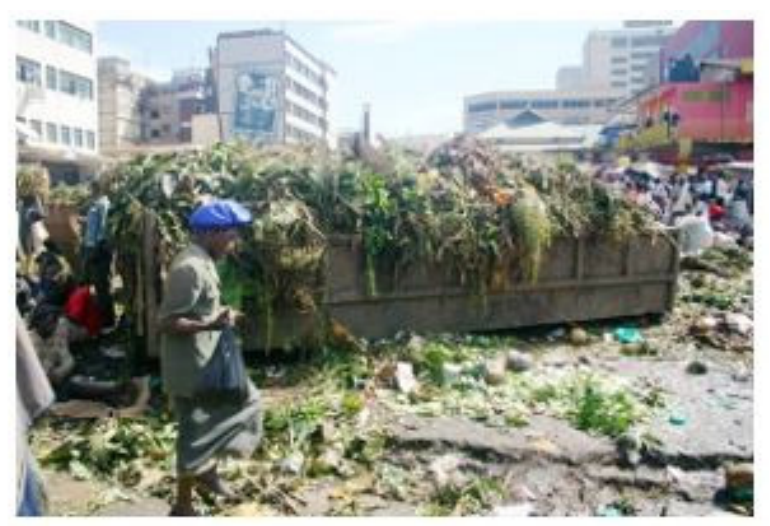

(b)

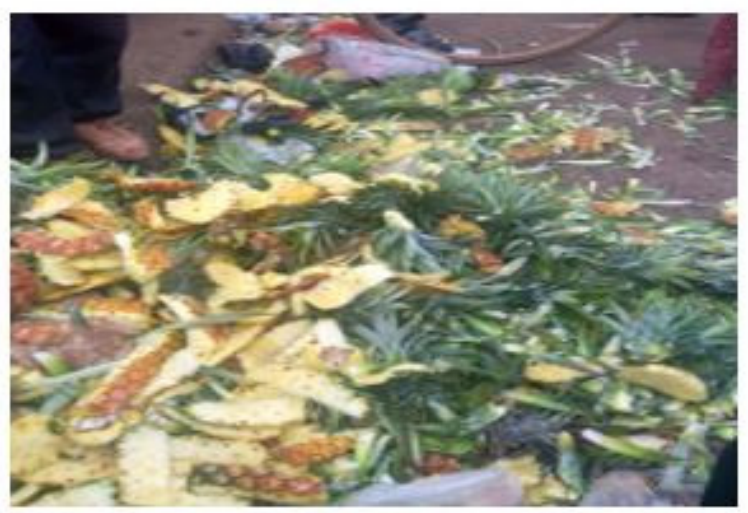

(d)

Figure 2. Market crop wastes generated within Kampala - Uganda, (a) Street scene at a market, (b) Residues of fruits and vegetables in a market (Lanyero, 2013), (c) Photo of an irresponsible waste collection point at St. Balikudembe market in Kampala (Schöbitz et al, 2014), (d) Pine apple peels collected in Nakasero market (Photo credit Noah Kisuule) 
Table 2. Nutritional composition of selected market crop wastes

\begin{tabular}{|c|c|c|c|c|c|c|c|}
\hline Crop waste & DM\% & Ash\% & СР\% & NDF\% & Ca $\mathrm{g} / \mathrm{kg}$ & P $\quad \mathrm{g} / \mathrm{kg}$ & Source \\
\hline & & & & & DM & DM & \\
\hline Banana peels & 9.40 & 9.28 & 8.10 & 41.38 & 2.90 & 1.80 & $\begin{array}{l}\text { Wadhwa \& Bakshi } \\
\text { (2013) and (Kabenge et } \\
\text { al., 2018) }\end{array}$ \\
\hline Cassava peels & 28.76 & 6.05 & 5.36 & 15.83 & 3.47 & 1.60 & Morgan \& Choct (2016) \\
\hline Pine apple peels & 88.60 & 4.81 & 9.13 & 36.30 & 4.90 & 1.30 & Huang \& Fang (2011) \\
\hline Mango peel & 92.20 & 6.10 & 4.60 & 25.87 & 8.10 & 2.80 & Yitbarek (2019) \\
\hline Mango kernel & 91.90 & 2.90 & 7.50 & 53.01 & 4.40 & 2.80 & Yitbarek (2019) \\
\hline Jack fruit waste & 92.50 & 3.78 & 15.10 & 4.20 & 61.10 & 2.22 & $\begin{array}{l}\text { Ndyomugyenyi } \\
\text { Mutetikka (2015) }\end{array}$ \\
\hline $\begin{array}{l}\text { Watermelon } \\
\text { rind }\end{array}$ & 98.90 & 7.87 & 2.00 & 30.00 & 0.29 & 1.35 & Zubairu et al., (2018) \\
\hline Cabbage leaves & 10.00 & 15.80 & 19.90 & 33.70 & 2.38 & 0.23 & $\begin{array}{l}\text { Wadhwa \& Bakshi } \\
(2013)\end{array}$ \\
\hline $\begin{array}{l}\text { Sweet potato } \\
\text { waste }\end{array}$ & 19.70 & 11.70 & 11.20 & 40.90 & 0.20 & 0.32 & Katongole et al., (2011) \\
\hline
\end{tabular}

Note. $\mathrm{DM}=$ Dry Matter; $\mathrm{CP}=$ Crude Protein; $\mathrm{NDF}=$ Neutral Detergent Fiber; $\mathrm{Ca}=$ Calcium; $\mathrm{P}=$ Phosphorus

Apart from fruits and vegetable, the common staple foods which are continually supplied throughout the year are also a major source of market waste. These include peelings from Banana (Matooke), Sweet potato (Lumonde), Cassava (Muwogo), Irish potatoes and legumes. The nutritional and mineral composition of various crop wastes have been compiled by several researchers as indicated in table 2 .

\section{Bioprocessing Technology, a General Perspective}

\subsection{Bioprocessing and Its Applications}

A bioprocess is the process that involves use of a living cell/microorganism or a cell component to obtain a desired end product (Moser, 2012; Olaoye \& Odewole, 2016). The process involves both transport of mass and energy in the systems (Harun et al., 2010). The bioprocessing technology is currently being used in a number of industries. These include; the chemical and pharmaceutical, food processing, oil and energy for example in production of bioenergy, and in cleaning of environment (Barragán-Ocaña et al., 2020; Jeguirim \& Limousy, 2018; Lee et al., 2019; Nandy, 2016). The process basically entails three steps namely; (1) Upstream processing, (2) fermentation process and (3) Downstream processing (Schuler, 1992). The Upstream process involves selecting and culturing of a microbial strain/inoculum (Dubey, 2019). The strain is identified by its ability to manufacture a specific product having the desired value. It also includes all the stages related to inoculum and media development and optimization of growth kinetics so that product development can progress exceptionally (Gronemeyer et al., 2014). Fermentation involves transformation of the substrate in to the required product (Li et al., 2014). It is done with the help of microbes/cells acquired from the upstream stage. A particular strain is put into the reactor to culture in nutrient medium. It's also important to maintain physio-chemical properties of the substrate and microbes so that the desired product is properly synthesized (Tripathi \& Shrivastava, 2019). Downstream processing involves recovery of the product and cells from the fermentation broth (Gronemeyer et al., 2014). This is usually done by separation and purification techniques like filtration, distillation, centrifugation and precipitation (Antecka et al., 2019; D‘Souza et al., 2013). It also includes concentration of the final product and disposal of waste or recycle.

\subsection{Bioprocessing of Crop Wastes}

Solid state fermentation (SSF) of crop waste has been proposed as the most suitable bioprocessing treatment method that can lead its use as poultry feed (Ajila et al., 2012; Parmar et al., 2019; Ravindran et al., 2018). SSF is the fermentation process where microorganisms are grown in an environment without free water, or with very low content of free water on solid substrate and complex material is converted into simpler forms (Murty et al., 2018). 
Fungi, bacteria and yeast are usually used in this process (Lizardi-Jiménez \& Hernández-Martínez, 2017; Pendey, 2003; Ravindran et al., 2018). SSF is widely applied in the field of livestock nutrition for production of enzymes, organic acids, vitamins, feed additives/boosters and detoxification of agro-residues (Parmar et al., 2019). High value added products/feeds can be produced through microbial fermentation of crop wastes using SSF technique. For effective fermentation process, pre-treatment of wastes either by physical, thermal, chemical or biochemical processing is required (Deshmukh et.al., 2018). It is essentially done to enhance the availability of bound nutrients. It also modifies the nature of waste in terms of quality, hazardous nature, ease of handling and recovery (Rani et al., 2012). Solid state fermentation can enrich the nutritive value of wastes and reduce the level of anti-microbial substances. Thus representing potential solution to feeding livestock animals and birds in developing countries (Parmar et al., 2019). The low-tech and simplicity involved in SSF make it a better bio-processing method over others (Webb and Manan, 2017). This makes it possible for many farmers (both on large and small scale) to process the feeds on-farm. Generally, the protein content of most market wastes is low protein that is between 4-16\% (Wadhwa \& Bakshi, 2013). According to Ajila et al. (2012), fungal growth by solid state fermentation can improve protein content of crop wastes by 10-15\%. Gélinas and Barrette (2007) also observed an increase of 7-8\% of protein content of after SSF of potato residues using yeasts. Besides protein, fungal fermentation increases the total lipid and fatty acids content of cassava peels (El-imam \& Adenike, 2019). In another study by Elyas et al. 2002, Fungal growth caused a decrease in the acid detergent fiber, neutral detergent fiber, increase in the bioavailability of nutrients, and decrease in the anti-nutritional factors, such as phytic acid, polyphenols, and tannins.

Another form of bioprocessing method which has currently gained much interest globally is the use of organic food/crop waste to culture insects (like houseflies and black soldier flies) and earthworms. These are then harvested, dried, milled and included in fish and poultry feed rations as protein source (Sogbesan et al., 2007). In nature, insects are a source of food for various poultry birds like local chicken, ducks and turkeys raised under free range system (Öztürk and Köse., 2017). Current studies indicate that, it is scientifically feasible to grow insects and earthworms on large scale (Onsongo et al., 2018; Zegeye, 2020). Many researchers have concluded that insects' protein content is much higher than that of conventional fish and soy-based feed (Istiqomah et al., 2017; Khan, S., Naz, S., Sultan, A., Alhidary, L. and Abdelrahman, 2016; Öztürk \& Köse, 2017). The Food and Agriculture Organization (FAO) also commends insects as an alternative source of protein in livestock feed (Huis et al., 2013). Since protein additives are the most expensive ingredient in poultry feed formulation (Khan et al., 2016; Ssepuuya et al., 2017), feeding birds with insects and earthworms is a viable alternative. Therefore, Bioprocessing is the most reasonable and efficient method in altering market waste to poultry feeds pertaining to its cost, potential, and generation of non-toxic feeds.

\section{Current State of Bio-Processing of Market Waste into Poultry Feeds in Uganda}

Unlike some industries like the food processing, brewery, chemical and pharmaceutical, bio-processing has not been fully appreciated in the poultry feed industry especially in recovering feeds from market crop residues. Physical pre-treatment methods like sorting, washing, wilting/drying, chopping and at times cooking are predominantly used by many farmers (Dione et al., 2015). Farmers treat the crop wastes for various reasons. Keeping away disease causing organisms is the major reason. This is followed by the desire to make the crop wastes more palatable and removal of unsafe materials such as plastic bags, metals, glasses and among others.

Solid state fermentation method has not been used anywhere by poultry farmers and feed manufacturers in Uganda. This is fairly due to limited research on the growth kinetics of microbes responsible for altering a particular crop waste into the required nutrient rich feeds. Growth kinetics of the microbes are important because for success of SSF, several factors like water activity, $\mathrm{pH}$, temperature, aeration, solid support to be used, type of micro-organism, type of fermenter/reactor and substrate to be used have to be considered (Sadh et al., 2018; Webb \& Manan, 2017).

On the other hand, earthworm rearing using crop wastes has been embraced by a few farmers. The earthworms are grown and fed on crop residues collected from different food markets upon payment of a small fee or sometimes free of charge during peak seasons. According to Tah (2018), farmers in Gayaza, breed earth worms as a source of protein for inclusion in the feeds. However, the technology is still limited to pilot and laboratory level. Several research and development projects on the technical, social and economic feasibility and possible social-economic effects are currently ongoing.

Other interesting projects include converting waste into black soldier fly larvae that is also harvested to meet protein demands of animals to avoid competition for protein with humans. For example, Bobo Eco Farm, a 10acre farm in the village of Lulagala in Mityana district is currently conducting several projects related to breeding of black soldier flies (Odyambo, 2016). The farm uses organic waste from rotting fruits and vegetables collected 
from markets and restaurants. It is developing the low- tech equipment to breed the larvae on large scale to substitute the expensive and scarce silver fish. The farm also offers insect breeding trainings to small scale poultry farmers in form of organized groups. However, all the attempts and work done are still under research and pilot scale level due to some nutritional and technical limitations (section 5).

\section{Current Limitation for Utilization of Market Crop Waste as Poultry Feed in Uganda}

\subsection{Nutritional Aspect}

There are many nutritional factors, such as protein concentration and its biological value, digestibility, level of energy, fats and carbohydrates, quantitative and qualitative composition of amino acids, vitamin, mineral content and the amount of fiber which determine the quality of byproducts as poultry feed. The nutritional limitations for using market crop wastes as feeds for poultry include;

- Variability in nutritional level and quantity of market waste.

- Presence of naturally occurring anti-nutritional and toxic factors.

- Presence of pathogenic micro-organisms.

- $\quad$ Need for nutrient supplementation.

\subsection{Technical Aspect}

In Uganda, the non-conventional feed resources, such as market waste and byproducts from food processing are underutilized or less utilized due to various technical reasons. The market wastes are scattered in different places, seasonal with unreliable supply. This makes it difficult for processing them throughout the year. The costs of market wastes are non-competitive and cheap for the farmers. Processing of market waste is difficult, costly, and problematic. Lack of managerial skills and capital resources for the purchase and operation of suitable technology and also lack of the marketability of the processed feeds from wastes also prevents the better utilization of market waste. Generally, poultry farmers have neither the resources and know-how nor the quantities of residues to take individual action. Limited knowledge on the composition of the residues, such as proximate component intake and nutritive values, is also an important factor for the development of utilization technology for crop residues. This is because there is no proper research and development efforts.

\section{Developmental Strategies for Processing Poultry Feed from Market Crop Wastes}

The quality of utilization of market waste as chicken feed depends on its abundance and the equipment used for its preparation, preservation, and improvement. Furthermore, the elaboration of suitable methods of collection, transportation, and processing helps to lower the costs and increase the nutritive value. The following strategies have been thought of in the objective to enhance the adoption and use of market waste as poultry feeds:

i. To ensure sustainability of using market crop wastes as poultry feeds, research on massive rearing of insects (such as black soldier flies) and earthworms is necessary. Knowledge on different microorganisms (bacteria, fungi and yeast) should also be gathered and taught to farmers. It is particularly important in urban areas where most markets are found. This should involve identifying the right and acceptable crop wastes in amounts that is appropriate for commercial production.

ii. There is a need for research partnerships between the private sector and research institutions, for commercialisation of mass production of feeds under solid state fermentations. Studies on growth kinetics for various species of micro-organisms under different crop wastes collected from markets should be facilitated. This is to find out the optimum conditions for commercialisation of the technology.

iii. There should be a systematic plan to implement research findings on use of crop waste feeds to the benefit of the stakeholders in poultry industry.

iv. Models that encourage insects rearing and SSF on a small and medium scale should be encouraged alongside industrial mass processing. This will promote sustainable production of feeds from market waste and also create employment opportunities. Therefore, leading to increased community awareness and acceptance of the technology.

v. Upon successful research on economic and technical feasibility, a supportive legal environment is required to facilitate the processing, trade and utilisation of market waste in the poultry feed industry. This therefore calls for involvement and collaboration between regulators, researchers and private sector.

vi. Prior to feeding, the nutritional composition of most market wastes has to be done in order to develop a proper feeding system for chicken. This is because each type of crop waste has differences in its nutritional composition compared to others. 
vii. In addition, the poultry farmers need to be educated through short extension classes or on-farm visits about the nutritional demands of poultry products and the development of best suitable feed alternatives for poultry birds.

\section{Conclusion}

The increasing demand for chicken and other poultry products has accelerated the demand for more protein rich feed stuffs globally. This has been seen in the rising costs of feed resources in the previous years. To meet these demands, the conventional feed stuffs are insufficient to fulfill the qualitative and quantitative parameters of poultry production. Therefore, more research should be conducted in order to investigate the partial use of alternative feed resources and ingredients to meet the growing demand for poultry products at low cost. Market crop waste could be a partial substitute for corn, fish and soy bean in poultry feed rations if appropriate technology is used. Sustainable conversion of market waste into poultry feed is possible by using bioprocessing techniques. This makes sense provided the maximum output in terms of the processed feed can be achieved with minimum inputs. The operating parameters and pre-treatment technologies available at a particular farm have to be thoroughly studied and optimized for maximum efficiency.

\section{Acknowledgment}

The authors are grateful to the colleagues at the department of Agricultural and Biosystems Engineering, Makerere University for their invaluable efforts which made this work a success.

\section{References}

Abondio, R. B., Komakech, A. J., Kambugu, R. K., Kiggundu, N., Wanyama, J., Zziwa, A., \& Kyamanywa, S. (2020). Assessment of Municipal Organic Solid Waste, as a Potential Feedstock for Briquette Production in Kampala, Uganda. Journal of Sustainable Bioenergy Systems, 10(02), 62-75. https://doi.org/10.4236/jsbs.2020.102006

Ajila, C. M., Brar, S. K., Verma, M., Tyagi, R. D., Godbout, S., \& Valéro, J. R. (2012). Bio-processing of agrobyproducts to animal feed. Critical Reviews in Biotechnology, 32(4), 382-400. https://doi.org/10.3109/07388551.2012.659172

Amoding, A. (2007). Supply potential and agronomic value of urban market crop waste. Makerere University. Retrieved from http://hdl.handle.net/10570/916

Antecka, A., Blatkiewicz, M., Boruta, T., Górak, A., \& Ledakowicz, S. (2019). Comparison of downstream processing methods in purification of highly active laccase. Bioprocess and Biosystems Engineering, 42(10), 1635-1645. https://doi.org/10.1007/s00449-019-02160-3

Barragán-Ocaña, A., Silva-Borjas, P., Olmos-Peña, S., \& Polanco-Olguín, M. (2020). Biotechnology and Bioprocesses: Their Contribution to Sustainability. Processes, 8(4), 436. https://doi.org/10.3390/pr8040436

D 'Souza, R. N., Azevedo, A. M., Aires-Barros, M. R., Krajnc, N. L., Kramberger, P., Carbajal, M. L., ... Fernández-Lahore, M. (2013). Emerging technologies for the integration and intensification of downstream bioprocesses. Pharmaceutical Bioprocessing, 1(5), 423-440. https://doi.org/10.4155/pbp.13.55

Deshmukh, R., Khardenavis, A. A., \& Purohit, H. J. (2018). Bioprocess for solid waste management. Optimization and Applicability of Bioprocesses, 73-99. https://doi.org/10.1007/978-981-10-6863-8_4

Dione, M. M., Pezo, D., Kyalo, G., Mayega, L., Nadiope, G., \& Lukuyu, B. (2015). Perception and practices of farmers on the utilization of sweet potato, and other root tubers, and banana for pig feeding in smallholder crop- livestock systems in Uganda. 27(11).

Dou, Z., Toth, J. D., \& Westendorf, M. L. (2017). Food waste for livestock feeding: Feasibility, safety, and sustainability implications. Global Food Security, December, 0-1. https://doi.org/10.1016/j.gfs.2017.12.003

Dubey, A. (2019). Recent trends in upstream bioprocessing and major. September. https://doi.org/10.13140/RG.2.2.22431.51369

El-imam, A. M. A., \& Adenike, S. F. (2019). Effect of fungal fermentation on proximate composition and in vitro performance of agrowastes used in animal feed. Ife Journal of Science, 21(3), 1-11. Retrieved from https://www.researchgate.net/publication/336675591

Elyas, S. H. A., Tinay, A. H. El, Yousif, N. E., \& Elsheikh, E. A. E. (2002). Effect of natural fermentation on nutritive value and in vitro protein digestibility of pearl millet. 78, 75-79.

Gélinas, P., \& Barrette, J. (2007). Protein enrichment of potato processing waste through yeast fermentation. Bioresource Technology, 98(5), 1138-1143. https://doi.org/10.1016/j.biortech.2006.04.021 
Georganas, A., Giamouri, E., Pappas, A. C., Papadomichelakis, G., Galliou, F., Manios, T., Tsiplakou, E., Fegeros, K., \& Zervas, G. (2020). Bioactive compounds in food waste: A review on the transformation of food waste to animal feed. Foods, 9(3), 1-18. https://doi.org/10.3390/foods9030291

Gronemeyer, P., Ditz, R., \& Strube, J. (2014). Trends in upstream and downstream process development for antibody manufacturing. Bioengineering, 1(4), 188-212. https://doi.org/10.3390/bioengineering 1040188

Harun, R., Singh, M., Forde, G. M., \& Danquah, M. K. (2010). Bioprocess engineering of microalgae to produce a variety of consumer products. Renewable and Sustainable Energy Reviews, 14(3), 1037-1047. https://doi.org/10.1016/j.rser.2009.11.004

Huang, Y. L., Chow, C. J., \& Fang, Y. J. (2011). Preparation and physicochemical properties of fiber-rich fraction from pineapple peels as a potential ingredient. Journal of Food and Drug Analysis, 19(3).

Huis, A. V., Mertens, E., Itterbeeck, J. V., Halloran, A., Klunder, H., Muir, G., \& Vantomme, P. (2013). Edible insects. Future prospects for food and feed security. In Food and Agriculture Organization of the United Nations (Vol. 171, Issue May). FAO Forestry Paper 171. Retrieved from https://www.researchgate.net/publication/239687589

Istiqomah, L., Sakti, A. A., Suryani, A. E., Karimy, M. F., Anggraeni, A. S., \& Herdian, H. (2017). Effect of feed supplement containing earthworm meal (Lumbricus rubellus) on production performance of quail (Coturnix coturnix japonica). Earth and Environmental Science, 8, 68-74. https://doi.org/10.1088/1755-1315

Jeguirim, M., \& Limousy, L. (2018). Strategies for bioenergy production from agriculture and agrifood processing residues. Biofuels, 9(5), 541-543. https://doi.org/10.1080/17597269.2018.1506277

Kabenge, I., Omulo, G., Banadda, N., Seay, J., Zziwa, A., \& Kiggundu, N. (2018). Characterization of Banana Peels Wastes as Potential Slow Pyrolysis Feedstock. Journal of Sustainable Development, 11(2), 14. https://doi.org/10.5539/jsd.v11n2p14

Katongole, C. B., Sabiiti, E., Bareeba, F., \& Ledin, I. (2011). Utilization of market crop wastes as animal feed in urban and peri-urban livestock production in Uganda. Journal of Sustainable Agriculture, 35(3), 329-342. https://doi.org/10.1080/10440046.2011.554318

Khan, S., Naz, S., Sultan, A., Alhidary, L. and Abdelrahman, A. (2016). Worm meal: a potential source of alternative protein in poultry feed. World's Poultry Science Journal, 72, 93-102. https://doi.org/10.1017/S0043933915000

Kinobe, J. R., Niwagaba, C. B., Gebresenbet, G., Komakech, A. J., \& Vinnerås, B. (2015). Mapping out the solid waste generation and collection models: The case of Kampala City. Journal of the Air and Waste Management Association, 65(2), 197-205. https://doi.org/10.1080/10962247.2014.984818

Komakech, Allan J., Banadda, N. E., Kinobe, J. R., Kasisira, L., Sundberg, C., Gebresenbet, G., \& Vinnerås, B. (2014). Characterization of municipal waste in Kampala, Uganda. Journal of the Air and Waste Management Association, 64(3), 340-348. https://doi.org/10.1080/10962247.2013.861373

Komakech, Allan John. (2014). Urban waste management and the environmental impact of organic waste treatment systems in Kampala, Uganda (Issue October). Swedish University of Agricultural Sciences, Uppsala and Makerere University, Kampala.

Lanyero, F. (2013, June 6). Waste in food chain hurting environment. Daily Monitor. Retrieved from https://www.monitor.co.ug/News/National/Waste+in+food+chain+hurting+environment++experts+say//688334/1872418/-/pufkyoz/-/monitor.co.ug

Lee, S. Y., Sankaran, R., Chew, K. W., Tan, C. H., Krishnamoorthy, R., Chu, D.-T., \& Show, P.-L. (2019). Waste to bioenergy: a review on the recent conversion technologies. BMC Energy, 1(1), 1-22. https://doi.org/10.1186/s42500-019-0004-7

Leib, E. B., Balkus, O., Rice, C., Maley, M., Taneja, R., Cheng, R., Civita, N., \& Alvoid, T. (2016). Leftovers for Livestock: A legal Guide for Using Excess Food as Animal Feed. Center for Health Law and Policy Innovation,August. Retrieved from https://www.chlpi.org/wp-content/uploads/2013/12/Leftovers-forLivestock_A-Legal-Guide_August-2016.pdf

Li, T., Chen, X. Bin, Chen, J. C., Wu, Q., \& Chen, G. Q. (2014). Open and continuous fermentation: Products, conditions and bioprocess economy. Biotechnology Journal, 9(12), 1503-1511. https://doi.org/10.1002/biot.201400084

Lizardi-Jiménez, M. A., \& Hernández-Martínez, R. (2017). Solid state fermentation (SSF): diversity of 
applications to valorize waste and biomass. 3 Biotech, 7(1). https://doi.org/10.1007/s13205-017-0692-y

Lohri, C. R., Diener, S., Zabaleta, I., Mertenat, A., \& Zurbrügg, C. (2017). Treatment technologies for urban solid biowaste to create value products: a review with focus on low- and middle-income settings. Reviews in Environmental Science and Biotechnology, 16(1), 81-130. https://doi.org/10.1007/s11157-017-9422-5

Mahgoub, O., Al-Mahrouqi, H., Al-Lawati, S., \& Al-Muqbali, R. (2020). Nutritional Value of Vegetable Wastes as Livestock Feed. Sultan Qaboos University Journal for Science [SQUJS], 24(2), 71. https://doi.org/10.24200/squjs.vol24iss2pp71-77

Mboowa, D., Banadda, N., Kiggundu, N., Kabenge, I., \& Komakech, A. J. (2015). Estimation of methane generation based on anaerobic digestion and mass balance at Kiteezi Landfill, 9(9), 741-746. https://doi.org/10.5897/AJEST2015.1922

Mboowa, D., Kabenge, I., Banadda, N., \& Kiggundu, N. (2017). Energy potential of Municipal Solid Waste in Kampala, a Case Study of Kiteezi Landfill Site. August.

Miito, G. J., \& Banadda, N. (2016). Waste to energy technologies for solid waste management a case study of Uganda. CIGR Journal Open Access, 18(3), 136-146.

Morgan, N. K., \& Choct, M. (2016). Cassava: Nutrient composition and nutritive value in poultry diets. Animal Nutrition, 2(4), 253-261. https://doi.org/10.1016/j.aninu.2016.08.010

Moser, A. (2012). Bioprocess technology: kinetics and reactors. Springer Science \& Business Media.

Murty, D. S., Pandya, P. R., Devalia, B. R., \& Patel, S. (2018). Solid state fermentation of crop residues and its use in livestock ration. Proceeding of XVII Biennial Animal Nutrition Conference on "Nutritional Changes for Raising Animal Productivity to Improve Farm Economy."

Nandy, S. K. (2016). Bioprocess Technology Governs Enzyme Use and Production in Industrial Biotechnology: An Overview. Enzyme Engineering, 05(01), 1-5. https://doi.org/10.4172/2329-6674.1000144

Ndyomugyenyi, E. K., Okot, M. W., \& Mutetikka, D. (2015). The nutritional value of soaked-boiled-fermented jackfruit (Artocarpus heterophyllus) seed meal for poultry. Journal of Animal and Poultry Sciences (JAPSC), 4(4), 49-57. Retrieved from http://www.japsc.com

Nsubuga, D., Banadda, N., \& Kiggundu, N. (2019). Innovations in Value-Addition of Agricultural By-Products in Uganda. Journal of Environmental Protection, 10(11), 1493-1506. https://doi.org/10.4236/jep.2019.1011089

Odyambo, G. (2016, December 5). Uganda: Farmers save money by making chicken feed with insects. Retrieved from https://wire.farmradio.fm/farmer-stories/uganda-farmers-save-money-by-making-chicken-feed-withinsects/

Olaoye, J. O., \& Odewole, M. (2016). Introduction to Food and Bioprocess Engineering Discipline. Introduction to Engineering Discipline, March, 79-90. Retrieved from https://www.researchgate.net/publication/298353913_Introduction_to_Food_and_Bioprocess_Engineering Discipline

Onsongo, V., Osuga, I. M., \& Gachuiri, C. (2018). Insects for Income Generation Through Animal Feed: Effect of Dietary Replacement of Soybean and Fish Meal with Black Soldier Fly Meal on Broiler Growth and Economic Performance Insects for Income Generation Through Animal Feed. Journal of Economic Entomology, 1-8. https://doi.org/10.1093/jee/toy 118

Öztürk, E., \& Köse, B. (2017). Evaluation of Worms as a Source of Protein in Poultry. Selcuk Journal of Agricultural and Food Sciences, 31(2), 107-111. https://doi.org/10.15316/sjafs.2017.27

Padam, B. S., Tin, H. S., Chye, F. Y., \& Abdullah, M. I. (2014). Banana by-products: an under-utilized renewable food biomass with great potential. Journal of Food Science and Technology, 51(12), 3527-3545. https://doi.org/10.1007/s13197-012-0861-2

Parmar, A. B., Patel, V. R., Usadadia, S. V, Rathwa, S. D., \& Prajapati, D. R. (2019). A solid state fermentation, its role in animal nutrition: A review. International Journal of Chemical Studies, 7(3), 4626-4633.

Pendey, A. (2003). Solid-State fermentation. Biochemical Engineering Journal, 13, 81-84.

Raji, I. O., \& Onu, P. (2017). Untapped Wealth Potential in Fruit for Uganda Community. International Journal of Advanced Academic Research, 3(1), 17-25. Retrieved from http://www.ijaar.org/articles/Volume3Number1/Sciences-Technology-Engineering/ijaar-ste-v3n1-jan17-p7.pdf

Rani, R. U., Kumar, S. A., Kaliappan, S., Yeom, I. T., \& Banu, J. R. (2020). Low temperature thermo-chemical 
pretreatment of dairy waste activated sludge for anaerobic digestion process. Bioresource Technology, 103, 415-424. https://doi.org/10.1016/j.biortech.2011.09.124

Ravindran, R., Hassan, S. S., Williams, G. A., \& Jaiswal, A. K. (2018). A review on bioconversion of agroindustrial wastes to industrially important enzymes. Bioengineering, 5(4), 1-20. https://doi.org/10.3390/bioengineering5040093

Sabiiti, E. (2011). Utilising Agricultural Waste to Enhance Food Security and Conserve the Environment. African Journal of Food, Agriculture, Nutrition and Development, 11(6), 1-9.

Sabiiti, E., Ledin, S., Sporndly, E., Bareeba, F., Drake, L., Mugisha, J., Ekbom, B., \& Kyamanywa, S. (2004). Urban / Peri Urban Market Garbage: A Hidden Resource for Sustainable Urban Agriculture and the Environment in Uganda. The Uganda Journal, 50, 102-109.

Sadh, P. K., Duhan, S., \& Duhan, J. S. (2018). Agro-industrial wastes and their utilization using solid state fermentation: a review. Bioresources and Bioprocessing, 5(1). https://doi.org/10.1186/s40643-017-0187-z

Sagar, N. A., Pareek, S., Sharma, S., Yahia, E. M., \& Lobo, M. G. (2018). Fruit and Vegetable Waste: Bioactive Compounds, Their Extraction, and Possible Utilization. Comprehensive Reviews in Food Science and Food Safety, 17(3), 512-531. https://doi.org/10.1111/1541-4337.12330

Schöbitz, L., Niwagaba, C. B., \& Strande, L. (2014). RRR Project - From Research to Implementation: Waste Supply availability in Kampala. 1-87. Retrieved from http://www.eawag.ch/fileadmin/Domain1/Abteilungen/sandec/publikationen/EWM/FS_Quantification_Cha racterisation/RRR_Research_to_Implementation_Kampala.pdf

Schuler, M. (1992). Bioprocess engineering: Basic concepts. Journal of Controlled Release, 22(3). https://doi.org/10.1016/0168-3659(92)90106-2

Shalini, R., \& Gupta, D. K. (2010). Utilization of pomace from apple processing industries: A review. Journal of Food Science and Technology, 47(4), 365-371. https://doi.org/10.1007/s13197-010-0061-X

Sogbesan, O. A., Ugwumba, A. A. A., Madu, C. T., Eze, S. S., \& Isa, J. (2007). Culture and Utilization of Earthworm as Animal Protein Supplement in the Diet of Heterobranchus longifilis Fingerlings. Journal of Fisheries and Aquatic Science, 8(1), 287-290. https://doi.org/10.3923/jfas.2007.375.386

Ssepuuya, G., Namulawa, V., Mbabazi, D., Mugerwa, S., Fuuna, P., Nampijja, Z., .. Nakimbugwe, D. (2017). Use of insects for fish and poultry compound feed in sub-Saharan Africa - A systematic review. Journal of Insects as Food and Feed, 3(4), 289-302. https://doi.org/10.3920/JIFF2017.0007

Tripathi, N. K., \& Shrivastava, A. (2019). Recent Developments in Bioprocessing of Recombinant Proteins: Expression Hosts and Process Development. Frontiers in Bioengineering and Biotechnology, 7. https://doi.org/10.3389/fbioe.2019.00420

Wadhwa, M., \& Bakshi, S. P. M. (2013). Utilization of fruit and vegetable wastes as livestock feed and as substrates for generation of other value-added products. In RAP Publication 2013-04 (FAO). https://doi.org/13578251

Webb, C., \& Manan, M. A. (2017). Design Aspects of Solid State Fermentation as Applied to Microbial Bioprocessing. Journal of Applied Biotechnology \& Bioengineering, 4(1), 511-532. https://doi.org/10.15406/jabb.2017.04.00094

Yabaya, A., \& Ado, S. (2008). Mycelial protein production by. World, 3(4), 9-12.

Yitbarek, M. (2019). Some Selected Vegetable and Fruit Wastes for Poultry Feed Vegetable and Fruit Wastes. Journal of Veterinary and Animal Research, 2(1), 1-7.

Zegeye, M. D. (2020). Nutritional Evaluation of Insect's Pupae-Larvae and its Utilization in Poultry Abstract. The Open Agriculture Journal, 14, 1-8. https://doi.org/10.2174/187433150

Zubairu, A., Gimba, A. S. B., Mamza, W. J., \& Highina, B. K. (2018). Proximate Analysis of Dry Watermelon (Citrullus lanatus) Rind and Seed Powder. Journal of Scientific and Engineering Research, 5(3), 473-478. Retrieved from www.jsaer.com

\section{Copyrights}

Copyright for this article is retained by the author(s), with first publication rights granted to the journal.

This is an open-access article distributed under the terms and conditions of the Creative Commons Attribution license (http://creativecommons.org/licenses/by/4.0/). 